NEI, M. (1978): Estimation of average heterozygosity and genetic distance from a small number of individuals. Genetics 89: 583-590.

NEI, M. (1987): Molecular Evolutionary Genetics. Columbia Uni. Press, New York.

Newton, A. C., Allnutt, T. R., Dvorak, W. S., Del Castillo, R. F. and EnNos, R. A. (2002): Patterns of genetic variation in Pinus chiapensis, a threatened Mexican Pine, detected by RAPD and RFLP markers. Heredity 89: 191-198.

PALMBERG, C. (1976): Geographic variation and early growth in south-eastern semi-arid Australia of Pinus halepensis Mill. and Pinus brutia Ten. species complex. Silvae Genetica 24 150-160.

Panetsos, C. P. (1981): Monograph of Pinus halepensis Mill. and P. brutia Ten. Annales Forestales (Zagreb) 9: 39-77.

PenG, S. L., LI, Q. F., LI, D., WANG, Z. F. and WANG, D. P. (2003): Genetic diversity of Pinus massoniana revealed by RAPD markers. Silvae Genet. 52(2): 60-63.

Stevens, M. T., Turner, M. G, Tuskan, G. A., Romme, W. H., GuNTER, L. E. and WALLER, D. M. (1999): Genetic variation in post fire aspen seedlings in Yellowstone National Park. Molecular Ecology 8: 1769-1780.
SzMidT, A. E, WANG, X. R. and LU, M. Z. (1996): Empirical assessment of allozyme and RAPD variation in Pinus sylvestris (L.) using haploid tissue analysis. Heredity 76: $412-420$

Weinstein, A. (1989a): Provenance variation of Pinus halepensis, P. brutia and P. eldarica in Israel. Forest Ecology and Management 26: 215-225.

Weinstein, A. (1989b): Geographic variation and phenology of Pinus halepensis, P. brutia and P. eldarica in Israel. Forest Ecology and Management 27: 99-108.

Welsh, J. and MCClelland, M. (1990): Fingerprinting genomes using PCR arbitrary primers. Nucleic Acids Research 18: 7213-7218.

Williams, J. G. K., Kubelik, A. R., LivaK, K. J., RAFAlski, J. A. and TingeY, S.V. (1990): DNA polymorphisms amplified by arbitrary primers are useful as genetic markers. Nucleic Acids Research 18: 6531-6535.

WRIGHT, S. (1969): Evolution and Genetics of Populations: The Theory of Gene Frequencies. Chicago: Univ. Chicago Press.

YeH, C. F., YANG, R. and Boyle T. (1999): POPGENE Version 1.31. Windows-based Software for Population Genetics Analysis.

\title{
Genotype x Environment Interaction in Maritime Pine Families in Galicia, Northwest Spain
}

\author{
By R. ZAS*, E. MerLo and J. FeRnÁNDEZ-LóPEZ
}

Dpto. Producción Forestal, Centro de Investigación Forestais e Ambientais de Lourizán. Apdo. 127, 36080 Pontevedra, Spain; phone: +34 986 805067; fax: +34 986 856420; E-mail: rzas.cifal@siam-cma.org.

(Received $13^{\text {th }}$ July 2004)

\begin{abstract}
Summary
The magnitude and practical importance of family $x$ site interactions for growth and form traits in maritime pine (Pinus pinaster Ait.) breeding in the coastal area of Galicia (NW Spain) were analysed using several different techniques. Data were from 58 8-yr-old half-sib families planted across four sites. The analysis of variance and the ratio of interaction to family variance component showed the interactions to be quantitatively important for several traits, especially for volume and straightness. Genetic correlations between the same trait at different sites were moderate and highly variable, especially for certain pairs of sites. The results indicated that interactions are a consequence of few highly interactive families that may be particularly sensitive to environmental variation. The removal of these families from the breeding program appeared as an effective strategy to solve the interactions. Results are discussed in relation to the stability parameter considered to identify the most unstable progenies.
\end{abstract}

Key words: Stability, Pinus pinaster, Progeny trial, Half-sibs, Genetic correlation.

\section{Introduction}

Maritime pine (Pinus pinaster Ait.) is the most important forest tree species in Galicia (NW Spain). It occupies around 400,000 ha ( $27 \%$ of the Galician wooded area) with an annual

\footnotetext{
*) to whom correspondence should be addressed.
}

volume increment estimated around $3 \cdot 10^{6} \mathrm{~m}^{3} \cdot \mathrm{year}^{-1}$ (XUNTADE-GALICIA, 2001).

Genetic improvement of $P$. pinaster in the coastal area of Galicia was initiated in 1985 and has included phenotypic mass selection in wild stands and use of this material for seed production in clonal seed orchard (MERLO and FERNÁNDEZLÓPEZ, 2004; VEGA et al., 1993). As in other countries, tree breeding objectives were focused mainly on improving growth traits (height and diameter), stem form and branch quality (AlAZARD, 2001; BUTCHER and Hopkins, 1993). Several progeny tests of the selected material have been established in the coastal area of Galicia across a range of environments. Heritability and genetic correlation in these tests have been estimated by ZAS et al. (2004). Results of this study indicate that height growth, internode length, number of whorls and branch angle are under stronger genetic control than diameter growth, stem straightness and forking, and would respond to individual selection. However, several of these traits have shown important genotype $\mathrm{x}$ environment $(\mathrm{G} \times \mathrm{E}$ ) interaction that must be analysed before any selection and/or recommendation is made.

The concept of $\mathrm{G} \times \mathrm{E}$ interaction has been defined as the varying relative performance of genotypes with environments (BURDON, 1977). An evaluation of the importance and the consequences of the $\mathrm{G} \times \mathrm{E}$ interaction in a breeding programme is essential for decision making about testing, deployment and selection strategies. There is substantial literature about the 
implications of the $\mathrm{G} \times \mathrm{E}$ interaction in many pine breeding programs such as Pinus radiata (JOHNSON and BURDON, 1990; Johnson, 1992; MATHESON and RAYMOND, 1984), P. elliottii (Pswarayi et al., 1997), P. patula (KANZler et al., 2003; SNEDDEN and Verryn, 1999), P. taeda (GwAZE et al., 2001), etc.

This paper uses 8-yr-old data from 58 half-sib Pinus pinaster families planted across four sites to investigate the importance and the practical implications of the $\mathrm{G} \times \mathrm{E}$ interaction in the Galician breeding program within the coastal area.

\section{Material and Methods}

\section{Genetic material, test sites and assessment}

Data for this study constitutes part of an operational breeding program aimed to provide genetically improved seed for practical reforestation in the coastal area of Galicia (NW Spain). The material consists of open pollinated families of first generation plus trees selected within the provenance ' $1 \mathrm{a}$, Noroeste Litoral' (ALÍA et al., 1996) for superior growth, stem form and branch characteristics (Figure 1). Different subsets of a total of 107 half-sib families were planted at four sites within the RIU (Region of Identification and Utilisation of forest reproductive material (GARCÍA et al., 2001)) number 1 (Figure 1) which constitute, a priori, the breeding area for the selected material. However, in the present paper, genotype $x$ environment interactions were investigated using the data of the 58 progenies represented in the four environments. Details of the

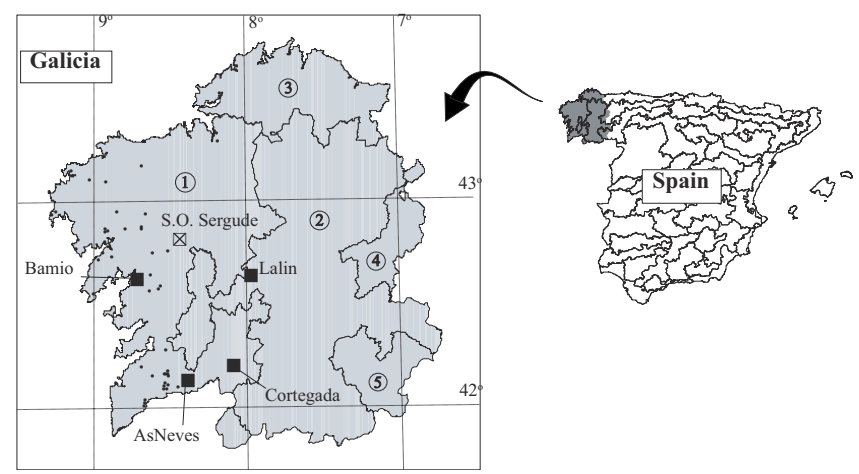

Figure 1. - Location of the Pinus pinaster plus trees, the clonal seed orchard (S.O.) and the four progeny tests. Encircled numbers indicate the number of the 'Identification and Utilization Regions' (RIUs) of forest reproductive material (GARCÍA et al., 2001). progeny tests, the genetic material and the genetic parameter estimates for growth, stem form and branch characteristic traits analysing all the 107 progenies have been presented elsewhere (ZAS et al., ZAS et al., 2004).

The sites are included within the Atlantic climate area, characterised by relatively high annual precipitation, low summer drought and low annual temperature oscillation (Table 1). Cortegada and Lalín sites show a slight Mediterranean influence with lower annual and summer precipitation (Table 1). All sites have acid and coarse textured soils with relatively low levels of nutrients. All the four trials followed a randomised complete block design with 10 replications of 5 -tree row plots with $3 \times 3 \mathrm{~m}$ spacing. Table 1 presents some descriptive values for each site and overall means for height and diameter.

All trees of each site were assessed for growth, stem form and branch characteristics at age 8 from planting, except those dead, dying or badly suppressed. Details of all the assessed traits are given in ZAS et al. (2004). In the present study only those traits that have shown significant $\mathrm{G} \times \mathrm{E}$ interaction were considered. These are: total height (HT), diameter at breast height $(\mathrm{DBH})$, a volume index $\left(\mathrm{V}=\mathrm{HT} \cdot \mathrm{DBH}^{2}\right)$, a stem straightness score (STR: $1=$ straight to $6=$ very crooked), a stem leaning score (LEN: $1=$ vertical to $4=$ sever lean), the number of whorls $(\mathrm{WH})$ and the average internode length $(\Delta \mathrm{H}=\mathrm{HT} / \mathrm{WH})$. Straightness and leaning were evaluated following the indications of GALERA et al. (1997).

\section{Statistical analyses}

A subset of 58 progenies common to the four test sites were considered for several types of analyses to determine the magnitude and practical importance of the $\mathrm{G} \times \mathrm{E}$ interaction.

A joint analysis of variance of the four sites together was conducted using plot mean values, since plots contained varying number of surviving trees and trees of the same family were planted together within a block. The following mixed model was considered:

$$
Y_{i j k}=\mu+F_{i}+S_{j}+F S_{i j}+B_{k}\left(S_{j}\right)+\varepsilon_{i j k}
$$

where $\mu$ is the overall mean, $S_{j}$ is the fixed effect of site $j$ and $F_{i}, F S_{i j}, B_{k}\left(S_{j}\right)$ and $\varepsilon_{i j k}$ are the random effects of the family $i$, the interaction between family $i$ and site $j$, the block $k$ within site $j$, and the random error, respectively. To analyse this mixed model the SAS MIXED procedure was used (SAS-INSTITUTE, 1999). This procedure estimates the variance components

Table 1. - Details of the Pinus pinaster progeny tests and overall means for height and diameter at age 8 for the 58 families under study.

\begin{tabular}{lcccc}
\hline & AsNeves & Bamio & Cortegada & Lalin \\
\hline Altitude (m) & 525 & 300 & 530 & 700 \\
Aspect & $\mathrm{E}$ & $\mathrm{N}$ & $\mathrm{S}$ & $\mathrm{S}$ \\
Slope (\%) & 24.9 & 26.8 & 5.2 & 17.6 \\
Parental origin & Granite & Granite & Schist & Schist \\
Average soil depth $(\mathrm{cm})$ & 84 & 47 & 61 & 59 \\
Annual precipitation (mm) & 1760 & 1730 & 1106 & 1202 \\
Summer precipitation $(\mathrm{mm})$ & 143 & 186 & 118 & 93 \\
Annual mean Temperature $\left({ }^{\circ} \mathrm{C}\right)$ & 12.6 & 13.1 & 12.6 & 11.3 \\
Overall height mean $(\mathrm{cm})$ & $509.1 \pm 3.3$ & $491.1 \pm 4.0$ & $561.2 \pm 4.0$ & $440.4 \pm 2.5$ \\
Overall diameter mean $(\mathrm{mm})$ & $10.1 \pm 0.08$ & $9.2 \pm 0.09$ & $10.0 \pm 0.10$ & $7.7 \pm 0.06$ \\
\hline
\end{tabular}


based on mixed model equations and the restricted maximum likelihood (REML) method, and gives the best unbiased predictors (BLUP) of the random effects (SAS-INSTITUTE, 1999).

The practical importance of the $\mathrm{G} \times \mathrm{E}$ interaction was evaluated for each trait by the ratio $\sigma_{\mathrm{fs}}^{2} / \sigma_{\mathrm{f}}^{2}$, where $\sigma_{\mathrm{f}}^{2}$ and $\sigma_{\mathrm{fs}}^{2}$ are the family and family $x$ site variance components estimated from the joint analyses. SHELBOURNe (1972) suggested, as an approximation, that the effect of family $x$ site interaction are 'likely to be serious on gains from selection and testing' when the interaction component reaches $50 \%$ or more of the family component of variance.

Type B genetic correlations between the same trait in different environments ( $\mathrm{x}$ and $\mathrm{y}$ ) were calculated according to BURDON (1977):

$$
r_{B}=\frac{r_{x y}}{h_{f(x)} \cdot h_{f(y)}}
$$

where $r_{x y}$ is the phenotypic correlation of family means and $h_{f(x)}$ and $h_{f(y)}$ are the square roots of the family heritabilities at each environment estimated on a within site basis (WRIGHT, $1976 \mathrm{p}$. 244)

To test whether the interaction was a result of a few families reacting more than others, different subsets of the 58 families were formed by deleting the $n$ most unstable families with $n$ varying from 0 to 29 . For each subset, the joint analysis was computed and the SHELBouRnE's (1972) ratio calculated. Several stability parameters were considered to identify the most unstable progenies:

- The ecovalence (WRICKE, 1962) which is the interaction variance for each family expressed in percent of the total interaction variance. Shuklas stability variance (SHUKLA, 1972) is linearly related to the ecovalence value and, expressed in percent, the two values will be identical for each genetic entry (Hill et al., 1998). The ecovalence values can thus be tested for statistical significance using the method described by SHUKLA (1972).

- The mean rank deviation (MATHESON and RAYMOND, 1984) estimated as:

$$
r d_{i}=\frac{1}{n} \cdot \sum_{j}\left|r_{i j}-\bar{r}_{i j}\right|
$$

where $r_{i j}$ is the ranking of the mean of the $i^{t h}$ family at the site $j$ and $\bar{r}_{i j}$ is the ranking of each family over all sites.

- The regression coefficient $b_{i}$ of each family mean upon the overall site means (FINLAY and WiLKInsON, 1963). The closer the mean values for a family follow the site mean, the closer the regression will be to 1 and the family will be considered to be an average stability. If $b_{i}>1$, the family is considered of low

Table 2. - Estimates of variance components (\%) and SHELBourne's

\begin{tabular}{|c|c|c|c|c|c|c|}
\hline Trait & Code & $\sigma^{2}$ & $\sigma^{2}$ ts & $\sigma^{2} b(s)$ & $\sigma_{e}^{2}$ & $\sigma_{\mathrm{fs}}^{2} / \sigma_{\mathrm{f}}^{2}$ \\
\hline Total height & HT & $1.7^{* *}$ & $1.8^{* *}$ & $48.5 * * *$ & 48.0 & 1.08 \\
\hline Diameter at breast height & $\mathrm{DBH}$ & $1.6 * *$ & $1.5^{*}$ & $40.7^{* * * * *}$ & 56.2 & 0.97 \\
\hline Volume index & V & $0.9 *$ & $1.8^{*}$ & $46.6^{* * *}$ & 50.7 & 2.01 \\
\hline Average internode length & $\Delta \mathrm{H}$ & $8.1 * * *$ & $3.0^{* * *}$ & $29.5 * \% *$ & 59.3 & 0.37 \\
\hline Straightness score & STR & $1.9 *$ & $2.9 *$ & $12.5^{* * *}$ & 82.7 & 1.56 \\
\hline Leaning score & LEN & $2.6^{* * *}$ & $1.8 *$ & $19.2 * * *$ & 76.4 & 0.70 \\
\hline Number of whorls & WH & $11.9 * * *$ & $5.7 * * *$ & $18.5 * * *$ & 63.9 & 0.48 \\
\hline
\end{tabular}
(1972) ratio $\left(\sigma_{\mathrm{fs}}^{2} / \sigma_{\mathrm{f}}^{2}\right)$ from the mixed model for all sites together.

Significance levels: $* * *=P<0.001, * *=P<0.01, *=P<0.05$.
Table 3. - Type B genetic correlation between the same traits in differ-

\begin{tabular}{|c|c|c|c|c|}
\hline Trait & & Bamio & Cortegada & Lalin \\
\hline \multirow[t]{3}{*}{$\overline{\mathrm{HT}}$} & AsNeves & 0.52 & 0.13 & 0.44 \\
\hline & Bamio & & 0.33 & 0.37 \\
\hline & Cortegada & & & 0.28 \\
\hline \multirow[t]{3}{*}{ DBH } & AsNeves & 0.51 & 0.12 & 0.80 \\
\hline & Bamio & & 0.42 & 0.92 \\
\hline & Cortegada & & & 0.51 \\
\hline \multirow[t]{3}{*}{ V } & AsNeves & 0.30 & -0.04 & 0.65 \\
\hline & Bamio & & 0.46 & 0.76 \\
\hline & Cortegada & & & 0.35 \\
\hline \multirow[t]{3}{*}{$\Delta \mathrm{H}$} & AsNeves & 0.78 & 0.68 & 0.72 \\
\hline & Bamio & & 0.48 & 0.59 \\
\hline & Cortegada & & & 0.71 \\
\hline \multirow[t]{3}{*}{ STR } & AsNeves & 0.30 & 0.52 & -0.18 \\
\hline & Bamio & & 0.49 & 0.40 \\
\hline & Cortegada & & & 0.75 \\
\hline \multirow[t]{3}{*}{ LEN } & AsNeves & 0.38 & 0.29 & 0.72 \\
\hline & Bamio & & 0.61 & 0.12 \\
\hline & Cortegada & & & 0.78 \\
\hline \multirow[t]{3}{*}{ WH } & AsNeves & 0.79 & 0.56 & 0.58 \\
\hline & Bamio & & 0.56 & 0.47 \\
\hline & Cortegada & & & 0.73 \\
\hline
\end{tabular}
ent environments.

stability and better adapted to good sites whereas coefficients lower than 1 are achieved by stable families better adapted to poor sites.

- The mean square deviations from the former regressions for each family, $S^{2} d_{i}$ (EBERHART and RUSSEL, 1966). This value indicates the predictability of the linear response of a family according to the environmental effect gradient.

The relationships between different stability parameters for the same trait and between the stability of different traits was analysed by Spearman rank correlation (SAS-INSTITUTE, 1990).

\section{Results}

Family and family $\mathrm{x}$ site variance components were significantly different from zero in all cases (Table 2). The ratios of

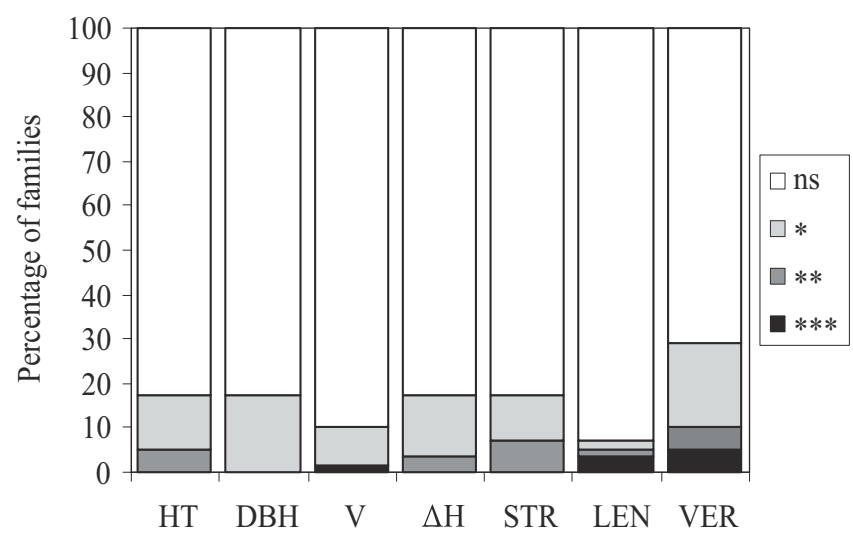

Figure 2. - Percentage of families that contribute significantly (SHUKLA, 1972) to the $\mathrm{G} \times \mathrm{E}$ interaction. 
interaction to family variance component $\left(\sigma_{\mathrm{fs}}^{2} / \sigma_{\mathrm{f}}^{2}\right)$ varied from 0.37 for $\Delta \mathrm{H}$ to 2.01 for $\mathrm{V}$, indicating different degrees of sensitivity to environmental changes among the studied traits. Following the SHELBOURNE (1972) criterion, all traits except $\Delta \mathrm{H}$ and $\mathrm{WH}$ showed family $\mathrm{x}$ site interaction of 'practical importance'.

Table 3 gives type B genetic correlation between environments. In the case of growth traits, slightly lower correlation
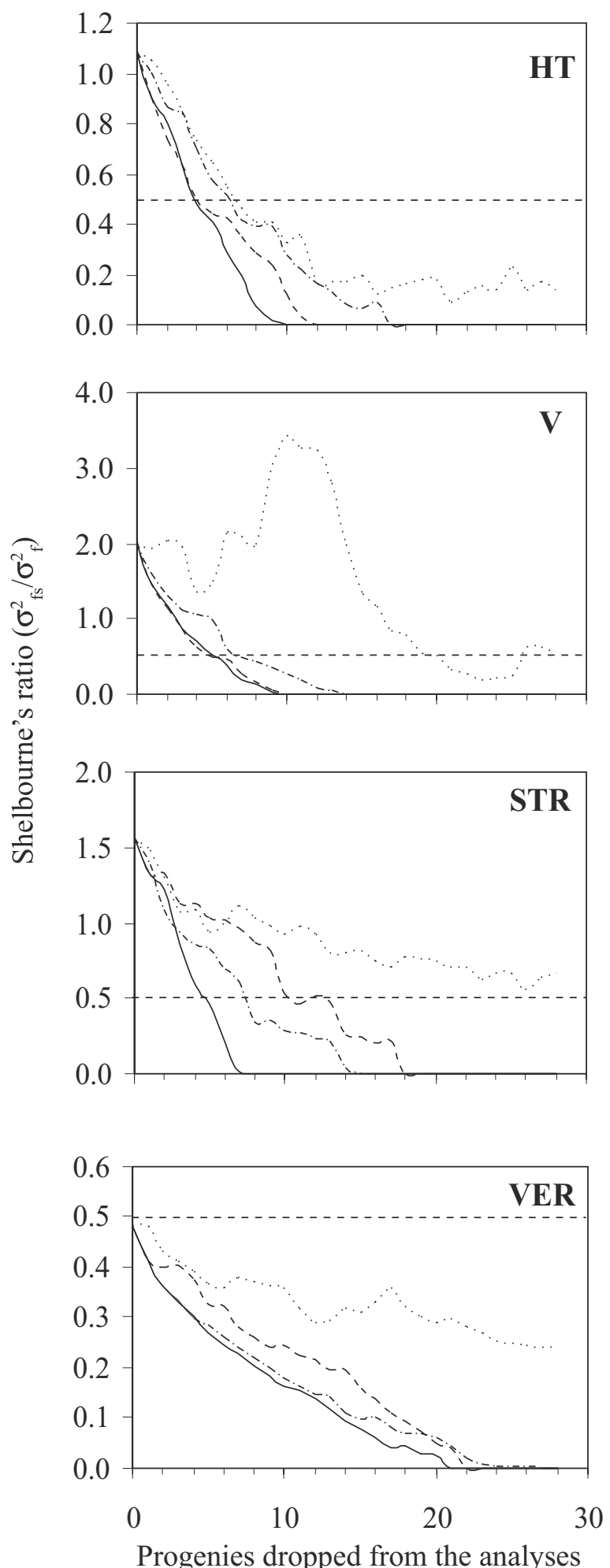

coefficients were observed for those pairs involving Cortegada, being AsNeves - Cortegada the pair with the lowest genetic correlation. In agreement with the lowest values of the $\sigma_{\mathrm{fs}}^{2} / \sigma_{\mathrm{f}}^{2}$ ratio, the genetic correlation for the number of whorls and the average internode length was moderate to high for all pairs indicating a relatively low incidence of the $\mathrm{G} \times \mathrm{E}$ interaction for these traits. The genetic correlation for straightness and leaning did not follow a clear pattern.
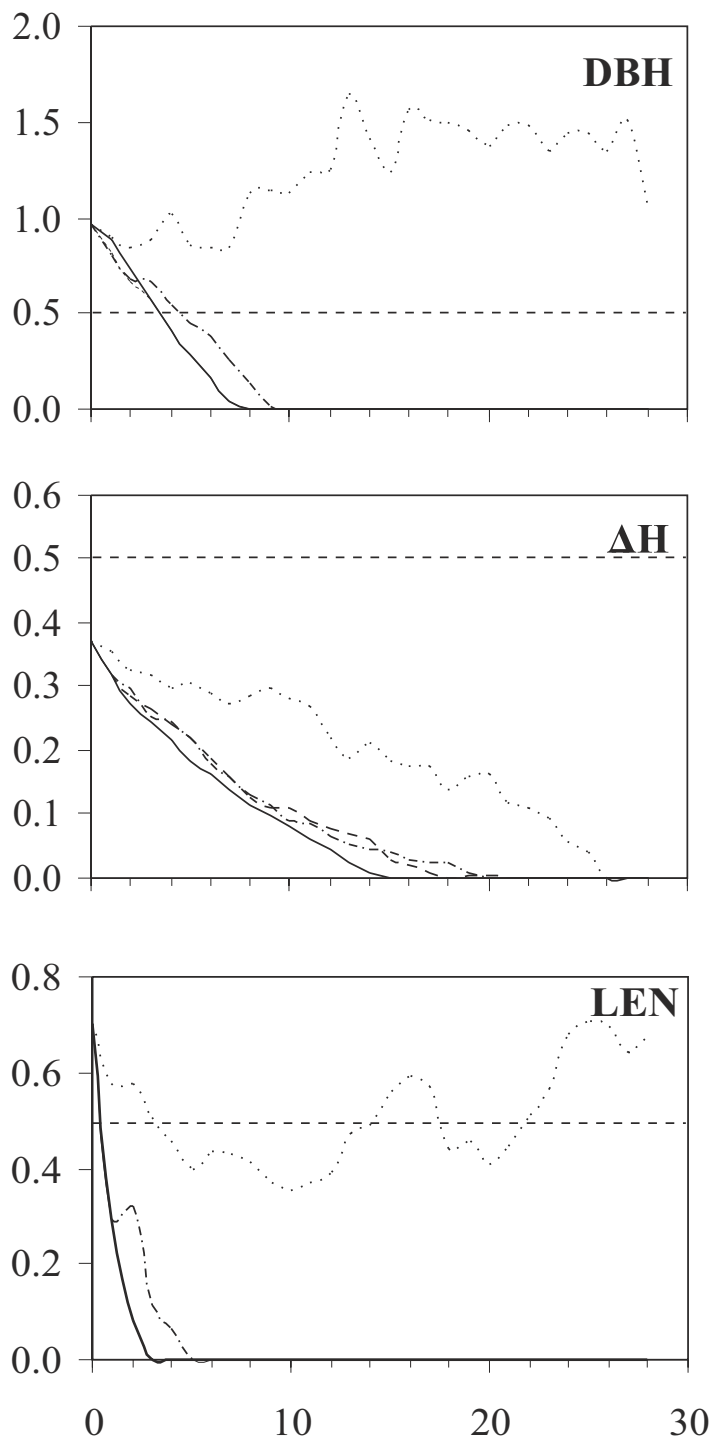

Progenies dropped from the analyses

Stability parameter considered:

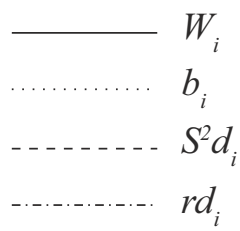

Figure 3. - Evolution of the SHELBournE's (1972) ratio $\left(\sigma_{\mathrm{fs}}^{2} / \sigma_{\mathrm{f}}^{2}\right)$ (ordinates) in terms of the number of unstable families dropped from the analyses (abscissas). The families dropped from the analysis are those with the highest values of different stability parameters $\left(W_{i}, b_{i}, S^{2} d_{i}, r d_{i}\right)$. 
Table 4. - Rank correlation coefficients of the stability parameters and the overall mean for each trait.

\begin{tabular}{|c|c|c|c|c|c|}
\hline Trait & Parameter & $b_{i}$ & $\mathrm{~S}^{2} \mathrm{~d}_{\mathrm{i}}$ & $W_{i}$ & $\mathrm{rd}_{\mathrm{i}}$ \\
\hline \multirow[t]{4}{*}{$\overline{\mathrm{DBH}}$} & Mean & 0.24 & -0.20 & -0.18 & -0.11 \\
\hline & $b_{i}$ & & -0.16 & -0.10 & -0.14 \\
\hline & $s^{2} d_{i}$ & & & $0.89^{* * * *}$ & $0.81 * * *$ \\
\hline & $W_{i}$ & & & & $0.84^{* * *}$ \\
\hline \multirow[t]{4}{*}{ HT } & Mean & -0.13 & -0.15 & -0.09 & -0.14 \\
\hline & $b_{i}$ & & 0.21 & 0.17 & 0.04 \\
\hline & $\mathrm{S}^{2} \mathrm{~d}_{\mathrm{i}}$ & & & $0.89 * * *$ & $0.72^{* * *}$ \\
\hline & $W_{\mathrm{i}}$ & & & & $0.83 * * *$ \\
\hline \multirow[t]{4}{*}{ V } & Mcan & $0.43^{* * *}$ & -0.05 & -0.05 & -0.06 \\
\hline & $b_{i}$ & & 0.03 & 0.02 & 0.00 \\
\hline & $\mathrm{S}^{2} \mathrm{~d}_{\mathrm{i}}$ & & & $0.93 * * *$ & $0.76^{* * *}$ \\
\hline & $W_{i}$ & & & & $0.87^{* * *}$ \\
\hline \multirow[t]{4}{*}{$\Delta \mathrm{H}$} & Mcan & -0.13 & 0.19 & 0.11 & 0.21 \\
\hline & $b_{i}$ & & 0.21 & 0.25 & 0.08 \\
\hline & $\mathrm{s}^{2} \mathrm{~d}_{\mathrm{i}}$ & & & $0.80^{* * *}$ & $0.75^{* * *}$ \\
\hline & $W_{j}$ & & & & $0.84 * * *$ \\
\hline \multirow[t]{4}{*}{ STR } & Mcan & 0.22 & 0.20 & 0.25 & 0.06 \\
\hline & $b_{i}$ & & -0.23 & -0.06 & -0.09 \\
\hline & $\mathrm{s}^{2} \mathrm{~d}_{\mathrm{i}}$ & & & $0.73^{* * * *}$ & $0.72^{* * *}$ \\
\hline & $W_{i}$ & & & & $0.86 * * *$ \\
\hline \multirow[t]{4}{*}{ LEN } & Mcan & 0.23 & $0.30 *$ & 0.14 & 0.09 \\
\hline & $b_{i}$ & & 0.05 & -0.03 & -0.12 \\
\hline & $S^{2} d_{i}$ & & & $0.76^{* * *}$ & $0.64^{* * * *}$ \\
\hline & $\mathbf{w}_{i}$ & & & & $0.82 * * *$ \\
\hline \multirow[t]{4}{*}{ WH } & Mcan & 0.01 & 0.10 & -0.03 & -0.10 \\
\hline & $b_{i}$ & & 0.06 & 0.05 & -0.12 \\
\hline & $\mathrm{s}^{2} \mathrm{~d}_{\mathrm{i}}$ & & & $0.87 * * *$ & $0.66^{* * *}$ \\
\hline & $w_{i}$ & & & & $0.80^{* * *}$ \\
\hline
\end{tabular}

The number of progenies that significantly contributed to the $\mathrm{G} \times \mathrm{E}$ interaction was relatively low for all traits (Figure 2), especially for volume and leaning. The distributions of the ecovalence values were skewed and the majority of families (more than $80 \%$ of the families except for $\mathrm{WH}$ ) contributed little to the interactions. These results suggested that removing a small number of unstable families from the analyses may substantially reduce the impact of the $\mathrm{G} \times \mathrm{E}$ interaction.

The reduction of the $\sigma_{\mathrm{fs}}^{2} / \sigma_{\mathrm{f}}^{2}$ ratio after deleting an increasing number of unstable progenies is presented in Figure 3. Different stability parameters were considered to identify the unstable families. The ecovalence $\left(W_{i}\right)$, the mean rank deviations $\left(r d_{i}\right)$ and the mean square deviations from regression lines $\left(S^{2} d_{i}\right)$ gave similar results, with a consistent reduction of the ratio when increasing the number of unstable progenies dropped from the analysis. However, when the slope of the regression lines, $b_{i}$, was considered as the stability parameter to identify the unstable progenies, results were confusing. In the case of $\mathrm{DBH}, \mathrm{V}$ and LEN, the $\sigma_{\mathrm{fs}_{\mathrm{s}}}^{2} / \sigma_{\mathrm{f}}^{2}$ ratio even increased when reducing the progenies considered in the analyses. Hence, the coefficient $b_{i}$ appeared as a poor stability parameter. In agreement with this, poor or even negative rank correlations between $b_{i}$ and the other stability parameters were observed (Table 4). On the contrary, Wi, $S^{2} d_{i}$ and $r d_{i}$ were highly significantly correlated among each other for all the studied traits (Table 4).

Nevertheless, Figure 3 shows that, for all traits, the interaction is quickly reduced to acceptable values by removing a small number of progenies. Considering 0.5 as the threshold for the $\sigma_{\mathrm{fs}}^{2} / \sigma_{\mathrm{f}}^{2}$ ratio above which $\mathrm{G} \times \mathrm{E}$ interaction becomes of 'practical importance' (SHElbourne, 1972), the 4-5 most unstable families should be removed in the case of HT, DBH, V and STR, only 1 in the case of LEN, and none for $\mathrm{WH}$ and $\Delta \mathrm{H}$, i.e. less than $10 \%$ of the families in all cases. The ecovalence value appeared as the best stability parameter to identify the unstable families to be removed and the biplots of the ecovalence values against the overall means (Figure 4 ) becomes an attractive tool for selection purposes. Those families of the right-down part of the graph are those with the better performance across all environments and show high stability. However, as it was shown in Figure 2 and Figure 3, only a very few number of
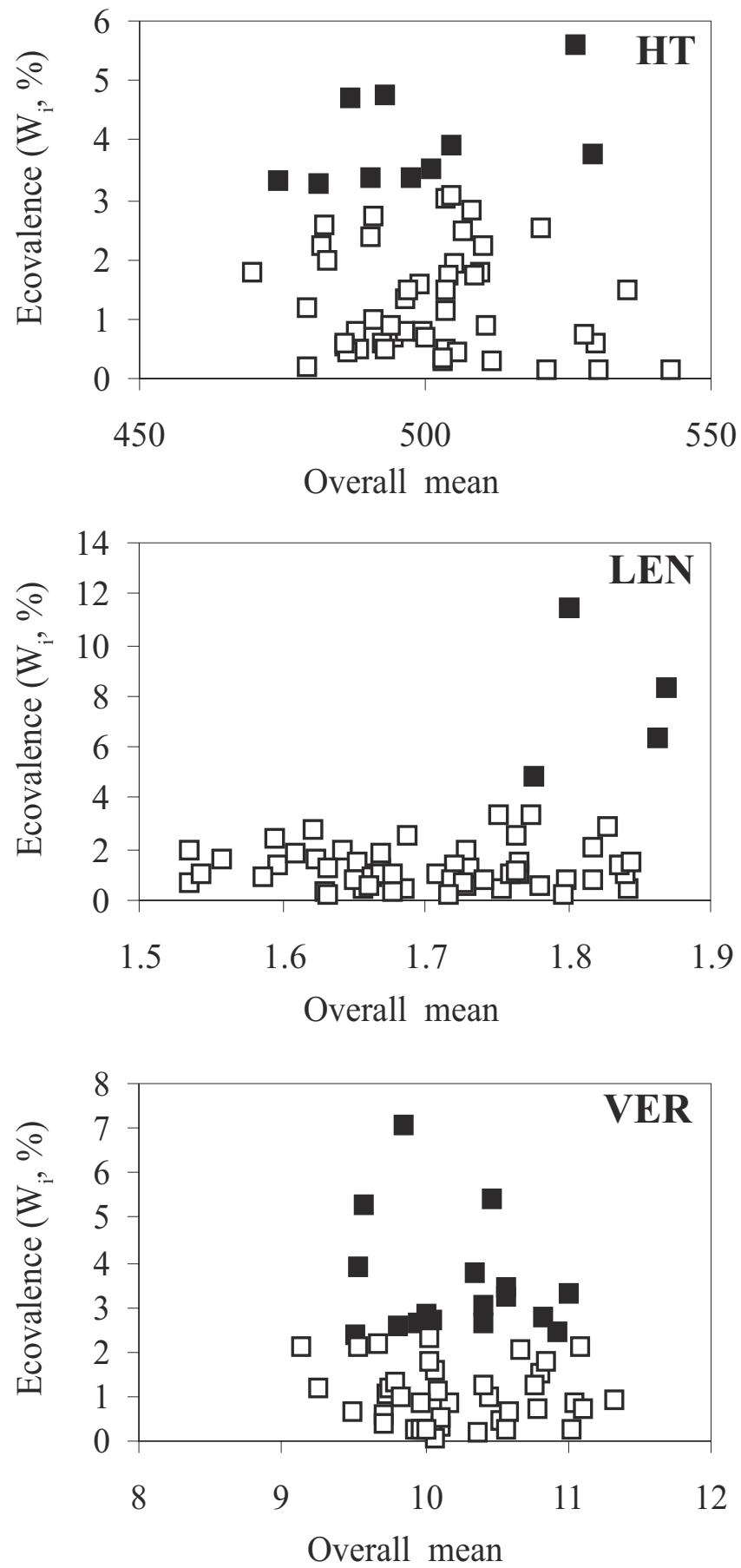

Figure 4. - Biplot of the ecovalence for the average internode length against the overall mean across all environments. Black squares indicate a significant contribution to the interaction variance (SHUKLA, 1972). 
families are really contributing to the $\mathrm{G} \times \mathrm{E}$ of practical importance and, hence, only a small number of families should be discarded due to high instability.

\section{Discussion}

Genotype $x$ environment interaction constitute an important limiting factor that affects the efficiency of breeding programs. When $\mathrm{G} \times \mathrm{E}$ is present and is quantitatively important, it cannot be ignored and breeders must decide between two major alternatives. The first approach is to define breeding zones that fit groups of genotypes with a similar pattern of $\mathrm{G} \times \mathrm{E}$ interaction and to select, independently within each zone, specifically adapted genotypes (WRIGHT, 1976 p. 252). The second approach is to identify stable and good general performers to use across a wide range of sites (FINLAY and WiLKINSON, 1963). Both alternatives have their own disadvantages. Regionalisation is costly and the additional gains from using regional breeds need to be weighed against the additional costs (JOHNSON and BURDON, 1990). Moreover, environmental variability within a region can be as high as between regions (MATHESON and CotTERILL, 1990), and the classification of sites to define and describe a breeding region is frequently hardly complicated (HILL et al., 1998). On the other hand, selection for generally adapted genotypes based on overall performance and stability across sites may imply a significant loss in the potential genetic gain. Furthermore, the evidence for the existence of truly broadly adapted genotypes is questionable (PsWARAYI et al., 1997). Examples of both alternatives can be easily found in Pinus breeding programs (AdAMs et al., 1994; JoHNSON and BuRdon, 1990; JOHNSON, 1992; KANZLER et al., 2003; MATHESON and RAYMOND, 1984).

Despite being small the area of study in which the test plantations are located, the G $\times \mathrm{E}$ is statistically significant and of practical importance (SHELBouRNE, 1972) for the three growth traits (HT, DBH and V), straightness, and leaning. In the case of volume, the interaction variance is more than $200 \%$ of the family variance, clearly higher than the threshold of SHELBOURNE (1972) and even higher than the critical value of $100 \%$ above which ERIKSSON and EKBERG (2001) suggested that there is a need for delineation of different breeding zones with separate breeding in each zone.

Moderate and highly variable genetic correlations were found among the test sites for growth and stem form traits (Table 3). In the case of growth traits, some pairs of tests were very poorly correlated suggesting that some sites, as Cortegada, may be distinctly different from the others. However, removing this site from the analysis reduced but not eliminated the impact of the $\mathrm{G} \times \mathrm{E}$ interaction (data not presented). Furthermore, there was no physical variable (Table 1) that clearly discriminated this site in relation to the others. Hence, there was no evidence that dividing or reducing the actual breeding area would improve the impact of the $\mathrm{G} \times \mathrm{E}$ interaction. Conversely, the results of this paper suggested that $\mathrm{G} \times \mathrm{E}$ interaction in all the studied traits are a consequence of few highly interactive families that may be particularly susceptible to environmental variation (Figure 2 and Figure 3). The removal of only the worst $10 \%$ families in this respect reduced the levels of interactions to a much more acceptable level (Figure 3). Hence, the most efficient solution to the problem of interactions would be to identify and discard interacting families and regard the rest of the families as being a unified breeding population for the whole studied area. Selections should then be made based on overall performance together with stability across sites. Similar conclusions have been reported for Pinus radiata in Australia (JoHnson, 1992; MATHESON and RAY-
MOND, 1984), and New Zealand (JOHNSON and BURDON, 1990), for Pinus elliottii in Zimbabwe (PSWARAYI et al., 1997) and for Douglas-fir in France (DUREL and ROMAN AMAT, 1987).

As pointed out by PSWARAYI et al. (1997) the sensitivity of stem form traits to environmental differences may be real or may be a consequence of the use of a standardised absolute assessment scale, and the relative difficulty of attempting to apply it across all sites. There has been considerable debate about the merits of standard versus site-specific scales for the assessment of stem straightness and other stem form traits (PsWARAYI et al., 1997; RAYMOND and CotTERILL, 1990; SIERRA dE Grado et al., 1999). Sierra de Grado et al. (1999) recommended an objective measure, such as the maximum deviation form the vertical, when more than one site is analysed.

To identify the unstable progenies, several stability parameters can be used. However, as observed elsewhere (e.g. SKRÖPPA, 1984), different parameters can give different rankings of the stability and, thus, results may differ (Figure 3). In fact, the stability parameters have different biological and statistical significance (see Hill et al., 1998). The relationships between the stability parameters (Table 4) were consistent across traits and were similar to those found by other authors (AliA et al., 1995; HiLl et al., 1998; SKRÖPPA, 1984). The high correlation between $W_{i}$ and $S^{2} d_{i}$ can be explained by mathematical relations between them (SKRÖPPA, 1984). The consistent relation between $W_{i}$ and $r d_{i}$ indicated that the ecovalence values reflected changes in ranks among sites. Stability in this sense is of maximum relevance for selection purposes and thus, both parameters appeared as the most useful for identifying the most unstable families. The lack of a relation between the regression coefficient $b_{i}$ with any other stability parameter may be explained by different meanings of these parameters. The coefficient $b_{i}$ reflects the portion of genotypic stability associated with the capacity of a genotype to perform relatively better in a favorable than in a unfavorable environment (HANSON, 1970). If genotypes with high values of $b_{i}$ are rejected the yield at the poor sites are increased at the expense of the yield at the good sites (SKRÖPPA, 1984) because high values of $b_{i}$ indicate good adaptation to high quality sites. The coefficient $b_{i}$ is, in fact, an adaptation parameter (FINLAY and WILKINSON, 1963; HiLL et al., 1998). Using a procedure similar to that described here, MATHESON and RAYMOND (1984) found a great reduction of the G $\times$ E impact across several Pinus radiata progeny test in Australia when the five most interacting families in terms of the mean rank deviations were omitted from the analysis. However, as found here, no reduction was achieved when the coefficient $b_{i}$ was used to discriminate the unstable families. It should be also noted that the regression coefficients $b_{i}$ were estimated upon only four sites and, thus, may be somewhat unreliable. SKRÖPPA (1984) recommended at least five points for these estimations.

The different stability parameters were independent of the respectively overall mean values for all traits with the exception of the significant relation between $b_{i}$ and the overall mean for $\mathrm{V}$ and between $S^{2} d_{i}$ and the overall mean for LEN (Table 4). In other studies the regression coefficient and the overall means are frequently related, indicating that the best genotypes are the most unstable. In these cases regression lines fan outwards as the environmental means increase. The stronger this correlation the more likely is the $\mathrm{G} \times \mathrm{E}$ interaction to be of the non-crossover type (HiLl et al., 1998 p. 164). The relative low rank correlation between bi and the overall mean for $\mathrm{V}$ and the very low, even negative correlations for the remainder traits (Table 4) suggest that interaction is mainly due to rank changes among sites. 
Table 5. - Rank correlation coefficients among the ecovalence values for different traits.

\begin{tabular}{|c|c|c|c|c|c|c|}
\hline & DBH & V & $\Delta \mathrm{H}$ & $\mathrm{REC}$ & INC & WH \\
\hline HT & $0.77^{* * *}$ & $0.78 * * *$ & 0.14 & -0.13 & $0.28^{*}$ & 0.22 \\
\hline DBH & & $0.89^{* \star *}$ & -0.07 & -0.25 & 0.24 & 0.26 \\
\hline V & & & -0.10 & -0.28 & 0.18 & 0.23 \\
\hline$\Delta \mathrm{H}$ & & & & 0.10 & 0.13 & -0.01 \\
\hline REC & & & & & $0.44 * *$ & -0.05 \\
\hline INC & & & & & & 0.13 \\
\hline
\end{tabular}

The lack of a correlation between the stability parameters and the overall means support the use of the stability - overall performance biplots (Figure 4) for selection purposes, provided that only one trait is under consideration. However, new problems arise for multi-trait selection. In this paper, $\mathrm{G} \times \mathrm{E}$ has shown to be of practical importance for several traits and it was concluded that stability for each trait should be considered when selecting. However, the stability parameters for the different traits are not always related (Table 5) indicating that the unstable families are probably not the same for all traits. In the case of growth traits, both the traits (data not presented) and their stability parameters are highly correlated (Table 5). The ecovalence of straightness and leaning were also significantly correlated. However, no relation was observed between the stability of the remainder pairs of traits (Table 5). Two major alternatives can be proposed. The first is the construction of a selection index that include both the performance and the stability of all the traits considered. The second approach is to select independently for each trait (combining both stability and overall performance using, for example, the biplots presented in Figure 4) and then to cross the selections by controlled pollinations, trying to combine both improvements in the offspring (WRIGHT, 1976, p. 315). Nevertheless, the lack of a significant negative correlation between the stability parameters facilitate the selection based on several parameters simultaneously (DUREL and Roman AMAT, 1987).

\section{Acknowledgements}

This study was supported by the INIA project RTA2-109. The series of trials was established by the co-ordination of G. VEGA. Nursery and plantation was under the supervision of MARIANO ARnedo. We thank Ricardo FerRadás, Agustin Quintairós, Sonia Queimadelos, Marisa Blanco, Pilar Soto and Maribel JUNCAL of the C.I.F.A. Lourizán and the students DAVID DÍAZ, ElíAS CABRERA and MARGA GARCÍA for field assessment.

\section{References}

Adams, W. T., White, T. L., Hodge, G. R. and Powell, G. L. (1994): Genetic parameters for bole volume in longleaf pine: Large sample estimates and influences of test characteristics. Silvae Genet. 43: 357-366.

AlazARD, P. (2001): Gain genetique des graines issues de la premiere generation de vergers de Pin maritime. Informations Forets, Afocel 628: 6 p.

Alía, R., GiL, L. and PARdos, J. A. (1995): Performance of 43 Pinus pinaster Ait. provenances on 5 locations in central Spain. Silvae Genet. 44(2-3): 75-81.

Alía, R., Martin, S., De Miguel, J., Galera, R., Agúndez, D., Gordo, J., Catalán, G. and GIL, L. (1996): Las regiones de procedencia de Pinus pinaster Ait. OA de Parques Nacionales. DGCONA, Madrid, 75 p.

BuRdon, R. D. (1977): Genetic correlation as a concept for studying genotype-environment interaction in forest tree breeding. Silvae Genet. 26(5-6): 168-175.
Butcher, T. B. and Hopkins, E. R. (1993): Realised gains from breeding Pinus pinaster. For. Eco. Manage. 58(3-4): 211-231.

Durel, C. E. and Roman Amat, B. (1987): Interaction famille x site dans un test tristationnel de descendances de Douglas (Pseudotsuga menziesii (Mirb.) Franco). Ann. Sci. For. 44(2): 189-209.

EBERHART, S. A. and Russel, W. A. (1966): Stability parameters for comparing varieties. Crop. Sci. 6: 36-40.

ERIKSson, G. and EkBERG, I. (2001): An Introduction to Forest Genetics. Swedish University of Agricultural Sciences, Uppsala, Sweden, 166 p.

Finlay, K. W. and Wilkinson, G. N. (1963): The analysis of adaptation in a plant breeding programme. Aus. J. Agric. Sci. 14: $742-745$.

Galera, R., Martin, S., Alía, R., Gordo, J., Aguado, A. M. and Notivol, E. (1997): Manual de selección de masas productoras de semillas. Evaluación de caracteres. Ministerio de Agricultura, Pesca y Alimentación. INIA, Madrid, $92 \mathrm{p}$.

García, J. M., De-Miguel, J., AlíA, R. and Iglesias, S. (2001): Regiones de Identificación y Utilización de material forestal de reproducción. Ministerio de Medio Ambiente. Serie Cartográfica, Madrid, $293 \mathrm{p}$.

Gwaze, D. P., Wolliams, J. A., Kanowski, P. J. and Bridgwater, F. E. (2001): Interactions of genotype with site for height and stem straightness in Pinus taeda in Zimbabwe. Silvae Genet. 50(3-4): 135-140.

Hanson, W. D. (1970): Genotypic stability. Theor. Appl. Genet. 40: $226-231$.

Hill, J., Becker, H. C. and Tigarstedt, P. M. A. (1998): Quantitative and ecological aspects of plant breeding. Chapman \& Hall, London, United Kingdom, 275 p.

Johnson, G. R. and Burdon, E. D. (1990): Family-site interaction in Pinus radiata implications for progeny testing strategy and regionalised breeding in New Zealand. Silvae Genet. 39(2): 55-62.

JoHnson, I. G. (1992): Familiy-site interaction in radiata pine families in New South Wales, Australia. Silvae Genet. 41(1): 55-62.

Kanzler, A., Hagedorn, S. F., Hodge, G. R. and Dvorak, W. S. (2003): Genotype by environment interaction for volume growth at 6 years of age in a series of five Pinus patula progeny trials in southern Africa. S. Afr. For. J. 198: 3-15.

Matheson, A. C. and CotTerill, P. P. (1990): Utility of genotype $\mathrm{x}$ environment interactions. For. Eco. Manage. 30(1-4): 159-174.

Matheson, A. C. and Raymond, C. A. (1984): The impact of genotype $\mathrm{x}$ environment interactions on Australian Pinus radiata breeding programs. Aus. For. Res. 14: 11-25.

MERLO, E. and FERNÁNDEZ-López, J. (2004): Análisis del balance parental reproductivo en un huerto semillero de Pinus pinaster. Investigacion Agraria, Sistemas y Recursos Forestales 13(2): 387-398.

Pswarayi, I. Z., BARnes, R. D., Birks, J. S. and Kanowski, P. J. (1997): Genotype-environment interaction in a population of Pinus elliottii Engelm. var. elliottii. Silvae Genet. 46(1): 35-40.

RAYMond, C. A. and CotTerill, P. P. (1990): Methods of Assessing Crown Form of Pinus radiata. Silvae Genet. 39(2): 67-71.

SAS-Institute (1990): SAS Procedures guide, Version 6, Third Edition. SAS Institute Inc., Cary, NC, 705 p.

SAS-InstiTUTE (1999): SAS/STAT User's guide, Version 8. SAS Institute Inc., Cary, NC, 3848 p.

Shelbourne, C. J. A. (1972): Genotype-environment interaction: its study and its implications in forest tree improvement. Procedings of the IUFRO Genetics-SABRAO joint Symposia, Tokio, p. 1-28.

SHUKLA (1972): Some statistical aspects of partitioning genotype - environmental interaction components of variability. Heredity 29: 237-245.

Sierra de Grado, R., Diez-Barra, R. and Alia Miranda, R. (1999): Evaluación de la rectitud del fuste en seis procedencias de Pinus pinaster Ait. Investigacion Agraria. Sistemas y Recursos Forestales 8(2): 264-278. 
SKRÖPPA, T. (1984): A critical evaluation of methods available to estimate the genotype $\mathrm{x}$ environment interaction. Studia Forestalia Suecica 166: 3-14.

SNEDden, C. L. and VerRYN, S. D. (1999): An investigation into the occurrence and nature of genotype by environment interaction in Pinus patula. S. Afr. For. J.(186): 67-75.

Vega, P., Vega, G., GonzÁlez, M. and Rodríguez, A. (1993): Mejora del Pinus pinaster Ait. en Galicia. Procedings of the I Congreso Forestal Español, Lourizán, Pontevedra, p. $129-134$.
WRICKE, G. (1962): Uber eine methode zur erfassung der ökologischen streubreite in feldversuchen. Zeitung für Pflanzenzüchtung 47: 92-96.

WRight, J. W. (1976): Introduction to forest genetics. Academic Press, New York, $463 \mathrm{p}$.

XunTA-DE-Galicia (2001): O monte galego en cifras. Xunta de Galicia, Dirección Xeral de Montes e Medio Ambiente Natural, Santiago de Compostela, $227 \mathrm{p}$.

Zas, R., Merlo, E. and Fernández-López, J. (2004): Genetic parameter estimates for maritime pine in the Atlantic coast of North-west Spain. For. Genet. 11(1): 45-53.

\title{
Seed Source Variation in Growth Performance of Eucalyptus camaldulensis Dehnh. of Australian Origin in India
}

\author{
By H. S. Ginwal*, Pradip Kumar, V. K. Sharma and A. K. Mandal \\ Division of Genetics and Tree Propagation, Forest Research Institute, P.O. I.P.E. \\ Kaulagarh Road, Dehradun 248195 (Uttaranchal) India
}

(Received 25 ${ }^{\text {th }}$ May 2004)

\begin{abstract}
Results of a provenance trial of Eucalyptus camaldulensis Dehnh. laid out in 2001 at Seothi $\left(30^{\circ}\right.$ N Lat., $76^{\circ}$ E Long. and $250 \mathrm{~m}$ altitude) Haryana, a semi-arid region of India are reported and discussed. Six seed sources from Australia viz. Laura River, Emu Creek, Degrey River, Wiluna, Kennedy River, Morehead River were evaluated from nursery stage (3 months) to field performance (2 year). Two sources viz. E.tereticornis (Helenvele, Qld) and FRI-4 a local seed source were used as control (check material). Significant differences between the seed sources at nursery stage were observed for collar diameter $(\mathrm{P}<0.05)$ and number of leaves $(\mathrm{P}<0.01)$. At age 2 years, significant differences between the seed sources $(P<0.05)$ were observed for height and field survival. The two seed sources viz. Emu Creek Petford, QLD and Laura river, QLD ranked first and second for height and survival at this age. Results indicate that genetic differences exist between the sources of $E$. camaldulensis. None of the traits assessed (viz. height, collar diameter, number of leaves, number of branches and survival) was found to correlate with any of the geographical coordinates of the site (latitude, longitude and altitude). There were fair differences between phenotypic and genotypic coefficient of variability. Heritability values were fairly high for height and clear bole length in comparison to collar diameter, number of branches and survival. The relative performance of these provenances was fairly consistent throughout the period of observation. The two sources viz. Laura river, QLD and Emu Creek Petford, QLD are recommended for potential source for plantation programme under semi-arid conditions.
\end{abstract}

Key words: Eucalyptus camaldulensis, variation, provenance, seed source, genetic improvement, productivity, heritability.

\section{Introduction}

Eucalyptus camaldulensis Dehnh. is perhaps the world's most widely distributed and used tree species for planting in

\footnotetext{
*Author for correspondence: (e-mail: ginwalhs@icfre.org; ginwalhs@rediffmail.com)
}

arid and semi-arid lands (ELDRIDGE et al., 1994). It is also one of the most variable species which ranges from latitude $12^{\circ} 48^{\prime}$ $\mathrm{S}$ on the Mary river in the northern territory to $38^{\circ} 15^{\prime} \mathrm{S}$ in south western Victoria, Australia (ELDRIDGE et al., 1994). The species has been recognized in northern and southern form based on the distribution and distinct morphological characters (ELDRIDGE et al., 1994). It grows in tropical and temperate climates with rainfall from $200 \mathrm{~mm}$ to $1100 \mathrm{~mm}$ annually. The success of this species as an exotic is attributed to its superiority to other species in production of wood on infertile and dry sites, its tolerance to drought and high temperature combined with rapid growth when water is available, deep penetration of roots, tolerance of periodic water logging and soil salinity, some degree of tolerance to frost, good coppicing ability and usefulness of wood (ELDRIDGE et al., 1994). The species has been introduced throughout the Mediterranean basin and various parts of Africa and southern Asia to produce wood for fuel, posts, poles, construction timbers, pulp and paper based industries and hardwood flooring.

Selection of the right seed source of the species for a given site or region is necessary for achieving maximum productivity both in plantation forestry as well as in agroforestry systems. Due to the popularity of $E$. camaldulensis for it's various uses, and special attributes mentioned above, it has been introduced in India on large scale particularly in southern parts. The information with regard to the performance of this species in different agroclimatic zones of India is very limited. KUMARVELU et al. (1995) reported better performance of $E$. camaldulensis provenances over $E$. tereticornis in southern part of India. They found four promising provenances of $E$. camaldulensis with respect to growth and survival viz. Katherine, Richmond, Gibu river and Gilbert river. Based on published information it may be said that provenances from Murray and Darling river system and adjoining areas of Victoria, South Australia and New South Wales have been found performing superior particularly in California (EMERY and LEDIG, 1987), as well as on sites with summer drought including in Israel 